\title{
A no-tendency tendency. Proper names in Polish translation. An analytical study on the basis of the Harry Potter series
}

\author{
Bartosz BUĆ \\ Uniwersytet Rzeszowski/ University of Rzeszów \\ E-mail: bartoszb@ur.edu.pl,
}

\begin{abstract}
Due to the fact that the Polish translation of the Harry Potter series by Andrzej Polkowski is one of the most popular and influential in the latest years it seems to be very interesting to find out what qualities make a translation as popular as the original text. Obviously, it can be assumed that there must be a wide range of conditions to be met. However, this paper focuses only on one aspect, namely proper names, which can be found in the books as the plot is set in a non-real world containing a significant number of nouns that were invented for the purpose of the scenery and action. Thus, they pose a real challenge for translators. What is more, the article aims at answering the question of tendencies in the use of translation procedures.
\end{abstract}

Keywords: translation procedures, translation strategies, translation techniques, proper names, Harry Potter

\section{Introduction}

There are probably not many books in the history of commercial literature that have been as successful as the Harry Potter series. According to the official fan page, the books have already been translated into 80 languages with 500 million books sold all over the world. ${ }^{1}$ Its Polish translation by Andrzej Polkowski has been read very willingly as well, what can be proved by some readers' polls ${ }^{2,3}$. That is why, it seems to be highly stimulating to find out what qualities make a translation as popular as the original text. Obviously, it can be assumed that there must be a wide range of conditions to be met. However, this paper focusses only on one aspect, namely proper names which can be found in the Harry Potter series very frequently as the plot is set in a non-real world containing a significant number of nouns that were invented for the purpose of scenery and action. Thus, they pose a real challenge for translators because one has to think about how to translate the elements of the world that do not

\footnotetext{
${ }^{1}$ cf. 500 million Harry Potter books have now been sold worldwide. Retrieved July 4, 2018 from https://www.pottermore.com/news/500-million-harry-potter-books-have-now-beensold-worldwide.

${ }^{2}$ cf. Raport: Polacy ksiązek już prawie nie czytają. A jeśli po coś sięgaja, to Sienkiewicz albo ,,50 twarzy Greya”. Retrieved July 4, 2018 from http://www.newsweek.pl/styl-zycia/raportczytelnictwa-w-polsce-ile-ksiazek-czytaja-polacy-,artykuly,409201,1.html.

3 cf. Jakie ksiażki czytaja Polacy? Retrieved July 4, 2018 from https://www.pulshr.pl/pogodzinach/jakie-ksiazki-czytaja-polacy,51210.html.
} 
exist in the culture of the source language, and even more so in the culture of the target language (cf. C. Nord 2005: 108). What is more, the article attempts at answering the question of tendencies in the use of translation procedures. In order to carry out a translational analysis a theoretical framework is needed defining terms and indicating methods of the research.

\section{Theoretical framework}

\subsection{Proper names}

In theory, names of single persons or objects are 'outside' languages, belong, if at all, to the encyclopaedia not the dictionary, have... no meaning or connotations, are therefore, both untranslatable and not to be translated (P. Newmark 1982: 70).

In the light of the above quote, M. Piotrowska (2010: 95) is of the opposite opinion. The scholar believes that there is no legitimate justification or convincing arguments to claim that the lack of connotative meaning in names should be perceived as a fact. In practice, she develops her approach assuming that proper names are of denotative and connotative nature what entails the need and possibility of their translation. It would be inappropriate not to agree with the above statement as most, if not all, proper names that can be found in the empirical part of this paper carry a certain meaning, e.g. Dumbledore (an insect) or Fluffy (an adjective describing certain qualities). Moreover, M. Piotrowska (ibid.) suggests that the connotative value of proper names depends on their application in the linguistic and extra-linguistic context as some of them can be used suggestively, allusively, ironically, as puns, as characteristic label names or nicknames. Taking into consideration the presented concepts, the first step taken by the translator is, therefore, to identify and comprehend the idea which is hidden in a given lexeme. Very often, hidden significations of proper names serve certain purposes. That is why, the second procedure is to think of how to render the connotations that are evoked by the lexeme in the source text (ST). However, the fact is that depending on the degree of their peculiarity different linguistic devices have to be applied in terms of the usage of translation procedures.

Following M. Piotrowska's (2010: 95-96) account, proper names can be divided into three major groups: geographical names, institutional names and proper names of people.

As regards geographical names, it can be stated that in most cases they are transferred literally with or without transliteration ${ }^{4}$ depending on how long the use of some names has been established. However, it should be stressed that this can be regarded solely as a tendency and not a general rule, e.g. Cambridge (Eng.) and Cambridge (Pol.) but Edinburgh (Eng.) and Edynburg (Pol.). In case of compound nouns which carry a certain meaning, the common noun component is replaced by

\footnotetext{
${ }^{4}$ According to T. Hrehovčík (2006: 50), transliteration is a translation technique which is usually used in order to spell words (e.g. place names) from languages that use a different alphabet. However, examples provided by M. Piotrowska (2010: 96) prove that transliteration can be a successful technique not only in languages that use different alphabets but also within languages that use the same alphabet, e.g. Edinburgh (Eng.) - Edynburg (Pol.).
} 
its lexical equivalent, whereas the proper name lexeme is transliterated, e.g. New York (Eng.) and Nowy Jork (Pol.).

When translating institutional names, the translator has to take into consideration the question of recognizability of a given institution. M. Piotrowska (2010: 96) claims that "leaving institutional names in their original form is quite a legitimate solution if their referents are not internationally acknowledged (are culture-specific), and as a consequence translating them would inevitably carry serious translation loss". Following this account, it can be claimed that in case of an institution that is internationally recognizable and has equivalents in different languages that have been already used in other translations, the translator is supposed to follow the given pattern, e.g. European Parliament (Eng.) - Parlament Europejski (Pol.) or create a new lexeme that would be comprehensible in the target culture (TC).

When it comes to proper names of people, M. Piotrowska (2010: 96) states that phonological and graphical forms of names carry certain qualities that are understandable in the source language (SL). Therefore, the translator's task is to express these characteristics in the target language (TL) by means of different translation procedures. Quoting E. Nida (1964: 194), M. Piotrowska (2010: 97) suggests undertaking the following measures:

a) complete adaptation of the sound of the borrowed word to the phonological system of the receptor language;

b) simple borrowing of the orthographic form of the proper name from the SL, without reference to the sounds or the orthographic strangeness in the receptor language;

c) a compromise which involves a distinction between well-known names and those which are unfamiliar. Familiar - are written as pronounced in the TL if there is no literary tradition. Unfamiliar - are adjusted to the phonological patterns of the language.

In the light of the above, it is therefore considered that there are no strict rules that translators are obliged to obey. The above quotation presents only possible solutions that can be adopted in order to solve the problem of transliterating proper names. Thus, it can be stated that the choice of an appropriate translation procedure is very much dependent on the experience and the esthetical perception of the translator. From this point of view, it can be expected that translation procedures presented in the empirical part of this paper are solely going to describe steps undertaken by the specific translator (i.e. Andrzej Polkowski) and not to assess whether they were correct or incorrect.

\subsection{Translation procedures}

As the term translation procedure has been already mentioned, it is advisable to remark that there are also synonymous expressions that indicate the same process defined by T. Hrehovčík (2006: 44) as particular steps taken by the translator in order to overcome the lack of equivalence. On the other hand, L. Venuti (2001: 240) refers to more general aspects claiming that they "[...] involve the basic tasks of choosing the foreign text to be translated and developing a method to translate it" 
defining them as strategies of translation. I. Burkhanov (2003: 170) writes more about the problem of terminology suggesting that the terms: 'translation procedures', 'techniques of translating', 'methods of translating', 'translation strategies' etc. can be defined as "[...] selection of appropriate linguistic means of the target language that are intended to account for various elements of the spoken or written discourse originally conducted in the source language within the framework of mediated bilingual communication". Thus, it can be claimed that all the notions can be regarded as synonyms, as they refer to the same linguistic devices indicating activities carried out by the translator. In the following analysis, the mentioned term is of great importance as it can be regarded as an indicator allowing not only to explain the decision of the use of a certain technique but also to study steps taken by the translator in a certain translational situation.

Over the course of many years, different linguists have developed various types of translation procedures. Some of them reduce the number of reference points and distinguish between general categories, such as domesticating and foreignizing strategies (cf. L. Venuti 2001: 240-244), whereas the others go into detail focusing only on certain properties of each procedure defining more types of translation techniques. Such a complex approach is represented by T. Hrehovčík (2006) who by integrating concepts of different scholars gives a clear overview of translation procedures. In his typology, the author distinguishes between eleven translation techniques that can be applied in order to solve the problem of lacking equivalence, i.e. adaptation, borrowing, calque, compensation, explicitation, modulation, paraphrase, simplification, translator's note, transposition, transliteration. Due to the fact that the focus of this paper is not on all of the mentioned translation strategies, only some of them, which can be identified in the course of the analysis, are going to be discussed in detail at the beginning of each subsection in the empirical part of the article.

\section{Empirical study ${ }^{5}$}

\subsection{Adaptation}

Adaptation, understood as a translation procedure and not a competitive form to translation $^{6}$, can be applied according to T. Hrehovčík (2006: 46) when the context presented in the source language text cannot be rendered in the TC of the translation. Therefore, the translator using this procedure strives for some form of re-creation. In general, it can be stated that adaption can be a satisfactory solution when two cultures in question mismatch.

\footnotetext{
${ }^{5}$ The presented analyses make up a combination of different fragments of an unpublished master's thesis entitled: The question of equivalence in the Polish translation of the novel Harry Potter and the Philosopher's stone which was successfully defended by the author of the article in June 2018 at the Wyższa Szkoła Lingwistyczna in Częstochowa.

${ }^{6}$ Adaptation may be understood as a set of translative operations which result in a text that is not accepted as a translation but is nevertheless recognized as representing a source text of about the same length (G.L. Bastin 2001: 5).
} 
As T. Hrehovčík (2006: 46f.) claims, the most common situations when adaption is used are:

cross-code breakdown: in case of lack of appropriate lexical equivalents in the TT;

situational inadequacy: when the context referred to in the ST cannot be rendered in the TC, as it does not exist;

genre switching: the shift from one text type to a different one often results in a global recreation of the ST;

disruption of the communication process: a different type of readership often entails the need for changes in style, content or presentation.

In order to face these problems, the translator can use the following adaptation techniques:

transcription of the original: a part of the ST can be reproduced word-for-word; omission: a part of the ST is not translated;

expansion: some extra information is added either in the main text or in footnotes;

exoticism: slang or dialect elements in the ST are substituted with rough equivalents in the TL;

updating: information which can be regarded as outdated or obscure is replaced by modern equivalents;

situational equivalence: some information is presented in a more familiar context than it is the case in the ST;

creation: only the essential message from the ST is conveyed into a new translation unit in the TT.

\begin{tabular}{|l|l|}
\hline \multicolumn{1}{|c|}{ ST } & \multicolumn{1}{c|}{ TT } \\
\hline 'Haven't I told you he's not going?' he & - Nie mówiłem ci, że on tam nie pójdzie? - \\
hissed. 'He's going to Stonewall High and & syknał. - Pójdzie do gimnazjum Stonewall \\
he'll be grateful for it. [...].' p. 63 & i będzie mi za to wdzięczny. p. 65 \\
\hline
\end{tabular}

Table 1. Adaptation: proper name of an institution.

In the example provided above, the reader of the ST comes across a name of a school Harry Potter was meant to go to, before having been set free by Hagrid from the Dursley family. Taking a closer look at the issue, it may turn out that the name of the school is not typical of the TC, as high schools are characteristic of the US or Scottish education system ${ }^{7}$, whereas the Dursleys live in England ${ }^{8}$. Nevertheless, the translator decided to use a technique of adaptation trying to make the name more comprehensible to the readers of the TT. Therefore, taking into account the age of the main character, the name 'Stonewall High' has been translated as 'gimnazjum

${ }^{7} \mathrm{cf}$. Education in the United States. Retrieved December 21, 2017 from https://en.wikipedia. org/wiki/Education_in_the_United_States; Education in Scotland. Retrieved December 21, 2 017 from https://en.wikipedia.org/wiki/Education_in_Scotland\#Secondary_school_naming. ${ }^{8}$ cf. Dursley family. Retrieved December 21, 2017 from http://harrypotter.wikia.com/wiki/Du rsley_family. 
Stonewall' which is equivalent to (lower) secondary schools in England. Thus, it can be claimed that in this case the name of the high school can be regarded as a kind of exoticism.

\subsection{Borrowing}

Following T. Hrehovčík's (2006: 47) account, 'borrowing' is a translation technique which can be applied when there is no lexical item in the TL carrying the meaning of the lexeme in the SL. Given that they are not subject to the naturalization in the $\mathrm{TL}$, they are usually printed in italics. Borrowing is not only used to create a new expression in the TL but also to introduce or preserve a particular climate of the term, e.g. glasnost, perestrojka, shaman.

\begin{tabular}{|c|c|}
\hline ST & TT \\
\hline $\begin{array}{l}\text { "And the Quaffle is taken immediately by } \\
\text { Angelina Johnson of Gryffindor - what an } \\
\text { excellent Chaser that girl is, and rather } \\
\text { attractive, too-'. p. } 199\end{array}$ & $\begin{array}{l}\text { - ...Angelina Johnson natychmiast przej- } \\
\text { muje kafla... cóż za wspaniały ścigający, ta } \\
\text { dziewczyna, no i przy tym taka ładna... } \\
\text { p. } 194\end{array}$ \\
\hline
\end{tabular}

Table 2. Borrowing: proper name of a common noun.

Although the underlined lexical item in the TT is not completely identical with the lexeme in the ST, as it was subject to "naturalization', it still can be considered as a borrowing. Probably, the fact that there is a similar lexeme (in the sense of its graphical form) in the TL that is familiar to the readers was decisive in this case. However, the word "kafel" is used in a different context and carries a totally different meaning, namely "a tile". Therefore, it can be stated that there is no lexical equivalent carrying the meaning of the lexeme in the SL which refers to a kind of ball played in a match. In such a situation, the translator could invent a completely new word (neologism) or apply a borrowing which is the case here. Consequently, the semantic field of the lexical item which already existed has been extended, and the word obtained a new meaning.

\begin{tabular}{|c|l|}
\hline \multicolumn{1}{|c|}{ ST } & \multicolumn{1}{|c|}{ TT } \\
\hline $\begin{array}{l}\text { 'This, 'said Wood, 'is the Golden Snitch, } \\
\text { and it's the most important ball of the lot. }\end{array}$ & $\begin{array}{l}\text { - To jest złoty znicz }- \text { oznajmił Wood - } \\
\text { kula najważniejsza ze wszystkich czterech. } \\
\text { [...]. p. } 181\end{array}$ \\
\hline
\end{tabular}

Table 3. Borrowing: proper name of a common noun.

A translation procedure similar to the one in the previous example is to be observed in this text passage. The name of the fourth and the most important ball used in Quidditch is subject to the naturalization process which involves adjusting its morphological and phonetic form to a word that already exists in the TL, i.e. 'znicz'. However, its meaning is different from the meaning carried by the SL word. In Eng-

${ }^{9}$ Naturalization - it adapts the SL word first to the normal pronunciation, then to the normal morphology of the TL (P. Newmark 1988:82). 
lish, the transitive verb 'to snitch' means "to take something you are not allowed to" 10 , whereas the noun 'znicz' means in Polish 'a candle'. However, in the context of sports, the word is also used for the 'Olympic torch' (Pol. znicz olimpijski) ${ }^{11}$. Nevertheless, the translation procedure discussed here is also an example of borrowing. Moreover, it should be also remarked that both in the ST and in the TT shortened forms are more common, i.e. 'Snitch' instead of 'Golden Snitch', and 'znicz' instead of 'złoty znicz'.

\begin{tabular}{|c|c|}
\hline ST & TT \\
\hline $\begin{array}{l}\text { 'The four houses are called Gryffindor, } \\
\text { Hufflepuff, Ravenclaw and Slytherin. [...]' } \\
\text { p. } 122\end{array}$ & $\begin{array}{l}\text { - Są cztery domy: Gryffindor, Hufflepuff, } \\
\text { Ravenclaw i Slytherin. p. } 123\end{array}$ \\
\hline
\end{tabular}

Table 4. Borrowing: proper name of a common noun.

The names of the four houses of Hogwarts could have been translated by the use of various techniques, e.g. calque. Then, Ravenclaw could be translated as 'Kruczy Szpon', which is an example of a word-for-word translation. However, the translator decided to keep the names used in the ST, which is typical of borrowing. By means of this translation procedure, it was possible to preserve the climate of ST.

\begin{tabular}{|l|l|}
\hline \multicolumn{1}{|c|}{ ST } & \multicolumn{1}{|c|}{ TT } \\
\hline $\begin{array}{l}\text { It was now reading the sign that said } \text { Privet } \\
\text { Drive }- \text { no, looking at the sign; cats } \\
\text { couldn't read maps or signs. p. } 3\end{array}$ & $\begin{array}{l}\text { Kot odczytywał teraz napis PRIVET } \\
\text { DRIVE - nie, tylko wpatrywat się w ta- } \\
\text { bliczkę z tym napisem, bo przecież koty nie } \\
\text { potrafią czytać, a tym bardziej studiować } \\
\text { map. p. 7 }\end{array}$ \\
\hline
\end{tabular}

Table 5. Borrowing: geographical name.

The text passage provided above illustrates another example of borrowing. Just like in the previous case (Table 5.), the translator could apply a calque (ul. Ligustrowa Pol.) or other techniques, like adaptation, for instance, in order to create a new name of the street where the Dursleys live. However, in order to preserve the climate of the scenery in which the action takes place, he decided not to change the name.

\begin{tabular}{|l|l|}
\hline ST & \multicolumn{1}{|c|}{ TT } \\
\hline $\begin{array}{l}\text { Neville was snoring loudly, but Harry } \\
\text { couldn't sleep. He tried to empty his mind }\end{array}$ & $\begin{array}{l}\text { Neville chrapał już głośno, ale Harry nie } \\
\text { mógł zasnąć. Starał się uwolnić od natłoku } \\
\text { - he needed to sleep, he had to, he had his } \\
\text { first Quidditch match in a few hours - but wiedział, że powinien się wyspać, } \\
\text { the expression on Snape's face when Harry } \\
\text { przecież za kilka godzin wystąpi w swoim } \\
\text { had seen his leg wasn't easy to forget. }\end{array}$ \\
\hline
\end{tabular}

\footnotetext{
${ }^{10} \mathrm{cf}$. snitch. Retrieved February 7, 2018 from https://www.macmillandictionary.com/diction ary/british/snitch_1.

11 cf. znicz. Retrieved February 7, 2018 from https://pl.pons.com/thumaczenie?q=znicz\&l=en pl\&in $=\& l f=$ en.
} 
Table 6. Borrowing: proper name of a common noun.

Another example of a borrowing is the name of the game played by the students of Hogwarts, i.e. "Quidditch". In this case, the lexical item in the SL has been transferred into the TL without any changes in its form. Solely the capital letter disappeared, and the equivalent in the TL is lowercased (quidditch), which can be traced back to the spelling rules in the TL.

\begin{tabular}{|l|l|}
\hline \multicolumn{1}{|c|}{ ST } & \multicolumn{1}{|c|}{ TT } \\
\hline $\begin{array}{l}\text { On the contrary, his face split into a wide } \\
\text { smile and he said in a squeaky voice that }\end{array}$ & $\begin{array}{l}\text { Przeciwnie, na jego twarzy zakwitł szeroki } \\
\text { uśmiech i zaskrzeczał tak, że przechodnie }\end{array}$ \\
made passers-by stare: 'Don't be sorry, my & zaczęli się oglądać: \\
dear sir, for nothing could upset me today! & - Niech szanownemu panu nie będzie przy- \\
Rejoice, for You-Know-Who has gone at & kro, bo dzisiaj nic nie może zepsuć mi \\
last! Even Muggles like yourself should be & humoru! Ciesz się pan ze mną, bo już nie \\
celebrating, this happy, happy day!'.p. 5 & ma Sam-Wiesz-Kogo! Wszyscy powinni \\
& się cieszyć, nawet mugole tacy jak pan! Bo \\
& to szczęśliwy, ach, jak szczęśliwy dzień! p. 9 \\
\hline 'A Muggle,' said Hagrid. 'It's what we call & - Mugol - odrzekł Hagrid. - Tak nazywa- \\
non-magic folk like them. [...]'. p. 57 & my zwykłych pozamagicznych gości. p. 59 \\
\hline
\end{tabular}

Table 7. Borrowing: proper name of a person.

In the text passages provided above, there can be observed another lexeme which had not existed in the TL, until the book was published. What is more, the quoted sentence is the first in the whole series about Harry Potter where the word occurs. Due to the lack of an appropriate word, it was necessary to create an equivalent that would render the meaning. Thus, the translator made up the lexeme "mugol" which can be regarded as a borrowing and refers to people who are not involved in the world of magic. What is more, it can be stated that the lexeme "muggle" had already existed in the SL. However, it had carried a slightly different meaning referring to someone who does not know about something or how to do something ${ }^{12}$. Thus, just with the publication of the Harry Potter's series its semantical field extended. Interestingly, an exact explanation of the meaning of the word appears not until page 57 in the ST and page 59 in the TT.

\begin{tabular}{|l|l|}
\hline \multicolumn{1}{|c|}{ ST } & \multicolumn{1}{|c|}{ TT } \\
\hline $\begin{array}{l}\text { One o' the only safe places left was Hog- } \\
\text { warts. Reckon Dumbledore's the only one }\end{array}$ & $\begin{array}{l}\text { Tylko w Hogwarcie jeszcze było bezpiecz- } \\
\text { nie. Dumbledore był jedynym gościem, } \\
\text { You-Know-Who was afraid of. Didn't dare } \\
\text { przed którym Sam-Wiesz-Kto wymiękał. } \\
\begin{array}{l}\text { try takin' the school, not jus' then, anyway. } \\
\text { p. 59 }\end{array}\end{array}$ \\
\hline
\end{tabular}

Table 8. Borrowing: proper name of a person.

\footnotetext{
${ }^{12}$ cf. muggle. Retrieved February 20, 2018 from https://www.macmillandictionary.com/dicti onary/british/muggle.
} 
The above text passage makes an example of a proper name of a person. The name of the headmaster of Hogwarts, 'Dumbledore', has been translated by means of a borrowing. In this case, the translator decided to maintain the original name used in the ST. This way, the translator indicated that the scenery and action take place in a country with different language and culture. However, it should be stressed that the name is also a common noun in Southwest English and carries a certain meaning denoting an insect (a bumblebee) which makes a characteristic noise resembling music $^{13,14}$. Thus, the applied translation technique entails a translation loss, too.

\subsection{Calque}

As T. Hrehovčík (2006: 47) states, 'calque' is a translation technique which is based on the literal translation. It means that particular elements of the expression in the SL are literally translated word for word. This strategy can be used for purposes of foreignisation. According to I. Burkhanov (2003: 179), calque can be applied to translate compound lexical items, language-specific collocations and names of various institutions, e.g. Übermensch (Ger.) - superman (Eng.), skyscraper (Eng.) drapacz chmur (Pol.).

\begin{tabular}{|l|l|}
\hline \multicolumn{1}{|c|}{ ST } & \multicolumn{1}{|c|}{ TT } \\
\hline $\begin{array}{l}\text { 'They were some of the first to come back } \\
\text { to our side after You-Know-Who disap- } \\
\text { peared. p. } 117\end{array}$ & $\begin{array}{l}\text { - Jedni z pierwszych przeszli na naszą stro- } \\
\text { nę, kiedy zniknął Sam-Wiesz-Kto. p. } 118\end{array}$ \\
\hline
\end{tabular}

Table 9. Calque: proper name of a person.

The underlined nickname, „You-Know-Who”, of the protagonist, Lord Voldemord, and its Polish equivalent, „Sam-Wiesz-Kto”, are an example of a calque. Although this translation technique, known also as 'literal translation' or 'word-for-word translation', assumes that each word in the SL is to be replaced with its equivalent in the TL, it is not completely the case here, but it can still be considered as such. The only difference between the lexeme in the ST and its equivalent in the TT consists in the fact that the pronoun "You" has been replaced with the pronoun "Sam" (Eng. alone) which refers semantically and grammatically to the mentioned pronoun in the ST, and can be understood as an emphasis used for stylistic purposes, like the expression "you alone" instead of simple "you". Due to the fact that the TL (in contrary to the SL) does not always require the use of a pronoun, since the verb form itself indicates the person who the verb refers to, a shortened version has been applied, i.e. "Sam-Wiesz-Kto", instead of "Ty-Sam-Wiesz-Kto", which is stylistically more appropriate.

\footnotetext{
${ }^{13}$ cf. dumbledore. Retrieved July 18, 2018 from https://www.collinsdictionary.com/dictionar y/english/dumbledore.

${ }^{14}$ cf. Symbolism of Albus Dumbledore's name in Harry Potter. Retrieved July 18, 2018 from https://literature.stackexchange.com/questions/72/symbolism-of-albus-dumbledores-namein-harry-potter.
} 


\begin{tabular}{|l|l|}
\hline \multicolumn{1}{|c|}{ ST } & \multicolumn{1}{|c|}{ TT } \\
\hline $\begin{array}{l}\text { 'And did he }- \text { did he seem interested in } \\
\text { Fluffy?' Harry asked, trying to keep his } \\
\text { voice calm. p. } 285\end{array}$ & $\begin{array}{l}\text { - A on... on zainteresował się Puszkiem? } \\
\text { zapytał Harry, starając się zachować spo- } \\
\text { kój. p. 275 }\end{array}$ \\
\hline
\end{tabular}

Table 10. Calque: proper name of a character (just like a proper name of a person).

The text passage provided above presents another example of a calque. The name of the three-headed dog, "Fluffy", carries a certain meaning and is meant to evoke clear associations among the readers of the ST. According to the Cambridge Online Dictionary, the adjective "fluffy" means: "soft and like wool or like fur: fluffy toys" Therefore, the name has an ironic character, as the dog in question is a frightening three-headed monster keeping watch on the precious Philosopher's Stone. In order to re-create the same stylistic and semantic effect in the TT, a synonymous expression has been applied. What is more, it can be claimed that the word "Puszek" is an appropriate one in this context and does not seem odd to the readers of the TT, as it is a common name for pets in Polish.

\section{Conclusions}

The above analyses make it evident the translator had the need to use various translation techniques in order to translate proper names which can be found in the presented fragments of the ST and the TT. When translating the name of an institution ('Stonewall High' - table 1.), the translator applied adaptation for making the name more comprehensible to the TT audience. In order to render names of balls used in Quidditch (a game played by the students of Hogwarts), the translator decided that the graphical and morphological similarity of the already existing lexemes in the TL is going to be decisive, what makes these examples a kind of a borrowing (tables 2 and 3). Further borrowing techniques are to be observed in the translation of names of the houses of Hogwarts ('Gryffindor', 'Slytherin', 'Hufflepuff', 'Ravenclaw'), as well as in the translation of the name of a street the Dursley family live in ('Privet Drive') (tables 4 and 5). In both cases, the SL lexemes have been completely transferred without any changes in their graphical form into the TL although all of them carry a certain meaning that is comprehensible to the SL audience. The borrowing can also be distinguished in the translation of the lexemes 'Quidditch' and 'muggle'. In the former case (table 6), the word makes up an example of a neologism in the SL that had not existed until the first book was published. Keeping the same form in Polish, the translator introduced a new lexeme in the TL, as well. The other case (table 7) refers to a word that had existed in the SL before the first publication of the novel, but it had been used in a different context. Adjusting the SL lexeme to the phonological and graphical rules of the TL, the translator also coined a new name in Polish. Translating names of the protagonists - 'You-Know-Who'

\footnotetext{
${ }^{15} \mathrm{cf}$. fluffy. Retrieved January 31, 2018 from https://dictionary.cambridge.org/dictionary/engl ish/fluffy.
} 
and 'Fluffy' - (tables 9 and 10) the translator applied a calque rendering in the TL qualities carried by the names in the SL. However, when translating the name of the headmaster of Hogwarts ('Dumbledore' - table 8) the translator used a borrowing which entailed a translation loss as the lexeme indicates an insect in the SL.

In conclusion, it can be stated that in the translation of the mentioned proper names three various translation strategies can be observed, i.e. adaptation, borrowing and calque. However, the most diversified translation procedure in the sense of a variety of its types seems to be the borrowing. Nevertheless, the analysed examples prove that strict rules cannot be set in terms of the usage of translation strategies. Moreover, it can be said that there are no clear tendencies, and the use of each translation procedure was very much dependent on the professional experience and the esthetical perception of the translator. Thus, it can be stated that the final effect of the translation and its success is subject to individual skills of the translator what can be regarded as an obvious general rule in case of any translation. What is more, it should be stressed that the paper did not attempt at assessing the translator's work. Much more its aim was to analyse steps taken by the translator and answer the question of tendencies in the application of translation procedures.

\section{Literature}

\section{Primary literature}

Rowling, J.K. (2014), Harry Potter and the Philosopher's Stone. London.

Rowling, J.K. (2000), Harry Potter i kamień filozoficzny [translated by Andrzej Polkowski]. Poznań.

\section{Secondary literature}

Bastin, G.L. (2001), Adaptation. In : M. Baker (ed.), Routledge Encyclopedia of Translation Studies. New York/ London, 5-8.

Burkhanov, I. (2003), Translation: Theoretical Prerequisities. Rzeszów.

Hrehovčík, T. (2006), Introduction to Translation. Rzeszów.

Newmark, P. (1982), Approaches to Translation. Oxford/ New York.

Nida, E. (1964), Toward a Science of Translating. Leiden.

Nord, C. (2005), Text Analysis in Translation. Theory, Methodology, and Didactic Application of a Model for Translation-Oriented Text Analysis. 2nd Edition. Amsterdam/ New York.

Piotrowska, M. (2010), Learning Translation - Learning the Impossible? A Course of Translation from English into Polish. Kraków.

Venuti, L. (2001), Strategies of translation. In: M. Baker (ed.), Routledge Encyclopedia of Translation Studies. New York/ London, 240-244. 